\title{
K-rich clinopyroxenes as mantle conveyers of crustal-derived components
}

André, L. ${ }^{1}$, Shatsky, V. S. ${ }^{2}$, De Corte, K. ${ }^{1,3}$, Sobolev, N.V. ${ }^{2}$, Navez, J. ${ }^{1}$, and Jagoutz, E. ${ }^{4}$

1. Section of Mineralogy-Petrography-Geochemistry, Royal Museum for Central Africa, B-3080, Tervuren, Belgium.

2. United Institute of Geology, Geophysics and Mineralogy, Russian Academy of Science, Siberian Division, Novosibirsk, 630090, Russia.

3.Department of Geology and Soil Sciences, University of Ghent, Krijgslaan, 281, B-9000, Ghent, Belgium.

4. Max-Planck Inst. f. Chemie, Abt. Kosmochemie, Saarstr.23, D-55128 Mainz, Germany.

Recent experimental studies (Edgar and Vukadinovic, 1993; Schmidt, 1996; Harlow, 1997) converge to demonstrate that $\mathrm{K}$ can reside in the cpx structure at high-pressures (4-14 GPa). To investigate the role of $\mathrm{K}$-rich cpx in controlling the alkali, $\mathrm{Sr}, \mathrm{Ba}, \mathrm{Nd}$ and $\mathrm{Pb}$ contents in upper mantle, these elements were determined with REE, Th and $U$ on specimens from two reported geological occurrences: K-rich diopsides from the ultra-high pressure (UHP) Kokchetav Massif and $\mathrm{K}$-rich omphacites inclusions from the Argyle lamproitic diamonds. The Laserprobe ICP-MS was used to achieve in-situ microanalyses on these cpx which generally occur as tiny inclusions in other UHP mineral phases or as remnants within retrograde parageneses.

All Kokchetav K-rich cpx correspond to high $\mathrm{MgO}$ diopsides with low jadeite and $\mathrm{Ti}-\mathrm{Cr}$ contents. Those found in the matrix range from $0.2-0.6 \mathrm{~K}_{2} \mathrm{O}$ wt.\%. They often show regular, tiny $(1-5 \mu \mathrm{m})$ to large $(0.7-1 \mathrm{~mm}$ width), K-feldspar lamellae that testify of reequilibration during decompression. The K-rich cpx from garnet clinopyroxenites have unusually high, crustal-like, Cs (0.8-2.3 ppm), $\mathrm{Rb}$ (1-25 ppm), and $\mathrm{Pb}(1-17 \mathrm{ppm})$ concentrations (Fig. 1), but normal $\mathrm{Ba}$ and light rare-earth contents, in comparison to K-poor lithospheric mantle diopsides. In contrast, their $\mathrm{Sr}$ content is rather low : 2-54 ppm. They display unwonted $\mathrm{Rb} / \mathrm{Cs}, \mathrm{Ba} / \mathrm{Rb}$ and $\mathrm{Ce} / \mathrm{Pb}$, all much lower than the uniform values of upper continental crust material (Fig. 1) and $\mathrm{K} / \mathrm{Rb}(>500)$ higher than crustal value $(\mathrm{K} / \mathrm{Rb}=250-290)$. K-rich $\mathrm{cpx}$ from pyroxene-dolomite rocks also incorporate geochemical anomalies $(\mathrm{Ba} / \mathrm{Rb}<1.5 ; \mathrm{K} / \mathrm{Rb}>4000 ; \mathrm{Ce} / \mathrm{Pb}<4)$, but lower $\mathrm{Rb}$ enrichment, and undetectable $\mathrm{Cs}$ contents. In contrast, the K-rich diopside inclusions within garnets are free of any visible exsolutions at the resolution of the back-scattered electron imagery. Their $\mathrm{K}_{2} \mathrm{O}$ content is either homogeneous (but extremely variable from one inclusion to another: 0.4-1.3 wt.\%) or decreasing from core $(1.1 \mathrm{wt} . \%)$ to rim $(0.4 \mathrm{wt} . \%)$. Their high $\mathrm{K}$ content is coupled to very high $\mathrm{Rb}$ and $\mathrm{Cs}$ abundances (Fig. 1).

The analyzed Argyle omphacite compare closely to the Kokchetav diopsides by their $\mathrm{Ba}-\mathrm{Zr}$ depletions as well as their $\mathrm{Rb}, \mathrm{Cs}, \mathrm{Pb}$ enrichments approaching the crustal abundances. They just differ by their much higher Sr concentrations. All $\mathrm{K} / \mathrm{Rb}, \mathrm{Rb} / \mathrm{Cs}, \mathrm{Ba} / \mathrm{Rb}$ and $\mathrm{Ce} / \mathrm{Pb}$ are different from those expected for Mid Ocean Ridge Basalts (MORB) (Fig.1), but the Rb, Cs data recall those of South African diamondiferous eclogitic cpx.

Our study indicates that both diopsidic and omphacitic K-rich cpx accommodate crustal-like amounts of $\mathrm{Rb}, \mathrm{Cs}$ and $\mathrm{Pb}$ under some peculiar geological conditions that also favor unusual alkali$\mathrm{Pb}$ redistributions. The K-rich fluids continuously released from subducted rocks from $2 \mathrm{GPa}$ to $9 \mathrm{GPa}$ are the most appropriate vectors to efficiently mobilize those elements. Fluids related to the 2GPa-dehydration of a subducted oceanic crust could however be ruled out because the element mobility in those fluids would generate low $\mathrm{Pb} / \mathrm{Sr}$ and high $\mathrm{Ba} / \mathrm{Rb}$ in the residual cpx, just the opposite of what is observed. The outstanding restriction of K-rich cpx to diamond-bearing lithologies implies a growth from fluids with high $\mathrm{K}$ and $\mathrm{C}$ activities. Phengite breakdown in a Kokchetav-like carbonate-rich environment is thus inferred as a potential mechanism to imprint the alkali- $\mathrm{Pb}$ signature on both K-rich diopside and omphacite. In the Kokchetav Massif, UHP phengite is absent from rock matrix but has been often recognized as inclusions in garnet, sometimes 
coexisting with K-rich diopside. This demonstrates that phengite and K-rich diopside were stable together, at some stage during the prograde UHP metamorphism, in agreement with experimental results (Schmidt, 1996). During progressive heating, phengite should melt at around $800^{\circ} \mathrm{C}$ (at $4 \mathrm{GPa}$ ) and $900^{\circ} \mathrm{C}$ (at $6 \mathrm{GPa}$ ) (Schmidt, 1996), with K-rich cpx and dolomite probably remaining behind as refractory phases. This should make phengite-derived major $(\mathrm{K})$ and trace $(\mathrm{Rb}-\mathrm{Cs}-\mathrm{Ba}-\mathrm{Pb})$ elements available for repartition between dolomite $(\mathrm{Ba}, \mathrm{Pb}), \mathrm{K}$-rich $\mathrm{cpx}(\mathrm{Rb}, \mathrm{Cs}, \mathrm{Pb})$ and a fluid enriched in $\mathrm{K}-\mathrm{Rb}-\mathrm{Cs}-\mathrm{Pb}$. This scenario is consistent with the dolomite geochemical features (Fig. 1), especially their high $\mathrm{Ba} / \mathrm{Rb}$ values which appear complementary to those of $\mathrm{K}$-cpx in terms of crustal balance.

Under UHP conditions ( $>6.5 \mathrm{GPa}$ ), most continentally derived materials are probably dense enough to penetrate the upper mantle with eclogites (Irifune et al., 1994). Subduction of UHP K-cpx-rich rocks (such as the Kokchetav garnet clinopyroxenites made up of 70-80 vol.\% of cpx) is therefore proposed as an ideal mechanism to recycle supracrustal $\mathrm{K}, \mathrm{Rb}, \mathrm{Cs}, \mathrm{Pb}, \mathrm{Sr}$, and $\mathrm{Nd}$ to the mantle. However, the narrow range of $\mathrm{Rb} / \mathrm{Cs}, \mathrm{Ba} / \mathrm{Rb}, \mathrm{Ce} / \mathrm{Pb}$ values in oceanic basalts (Fig. 1) precludes any large contamination of ordinary mantle by subducted $\mathrm{K}$-cpx-rich materials. Owing to their low $\mathrm{Rb} / \mathrm{Cs}, \mathrm{K}$-cpx from diamondiferous eclogites, Argyle diamonds, and UHP metasediments appear complementary to MORB-OIB mantle sources with respect to the chondritic value. They could thus help to close the global balance of those elements with the lithospheric mantle, the depleted mantle, and the continental crust. A similar conclusion could be reached for $\mathrm{Ce} / \mathrm{Pb}$ in terms of the bulk silicate earth stock of $\mathrm{Ce}$ and $\mathrm{Pb}$. Our dataset is thus consistent with the existence of one or several, old (at least Proterozoic according to the Argyle specimens) concealed diamondiferousmetasedimentary-eclogitic (DIME) mantle reservoirs in addition to the depleted mantle and the continental crust. This emphasizes storage of "MORB-OIB" and "DIME" reservoirs in two essentially unmixed regions from the mantle.

Our results support the idea of occasional exchanges between "MORB-OIB" and "DIME" reservoirs as an explanation for the OIB isotopic features. $\mathrm{K}$-cpx have $\mathrm{Rb} / \mathrm{Sr} \mathrm{1-20}$ fold higher than the primitive mantle values $(0.03)$, but $\mathrm{U} / \mathrm{Pb}-\mathrm{Th} / \mathrm{Pb} 100$ times lower than the mantle ratios $(0.114$ and 0.46). Little admixture of a K-cpx-rich component to a "MORB" source would therefore destroy the magmatic derived correlation between these ratios, with the capacity of causing the wellknown lack of correlation for $\mathrm{Sr}-\mathrm{Pb}$ isotopes in OIB. The Kokchetav K-cpx-rich rocks display radiogenic $\mathrm{Sr}$ and $\mathrm{Pb}$ signatures $\left({ }^{87} \mathrm{Sr} /{ }^{86} \mathrm{Sr}: 0.78-0.79 ;{ }^{208} \mathrm{~Pb} /{ }^{204} \mathrm{~Pb}: 41.8-44.4\right)$ and unradiogenic $\mathrm{Nd}$ compositions $\left({ }^{143} \mathrm{Nd} /{ }^{144} \mathrm{Nd}: 0.51110-0.51238\right)$. Owing to their very low $\mathrm{Sr}$ contents, if they were recycled in limited amounts ( 1 to $5 \mathrm{wt} . \%$ ) within a depleted mantle source, they would produce a source with HIMU-like $\mathrm{Sr}-\mathrm{Nd}-\mathrm{Pb}$ isotopic features (Fig.2). However, there is no Kokchetav mixtures with a depleted mantle that could fit the EM1-EM2 Pb isotopic characteristics (Fig. 2b). Proterozoic or Archean analogs might do, if they have remained isolated for a long time in a DIME reservoir to evolve a sufficiently retarded radiogenic $\mathrm{Pb}$ growth compared to the depleted mantle.

\section{References}

Edgar, A.D. \& Vukadinovic, D. 1993, Potassium-rich clinopyroxene in the mantle an experimental investigation of a K-rich lamproite up to $60 \mathrm{kbar}$ : Geochim. Cosmochim. Acta 57, p. 5063-5072.

Harlow, G.E. 1997, K in clinopyroxene at high pressure and temperature: an experimental study: American Mineralogist 82, p. 259-269.

Irifune, T., Ringwood, A.E. \& Hibberson, W.O. 1994, Subduction of continental crust and terrigenous and pelagic sediments: an experimental study: Earth Planet. Sci. Lett. 126, p.351-368 . Schmidt M.W. 1996, Experimental constraints on recycling of potassium from subducted oceanic crust: Science 272, p.1927-1930. 

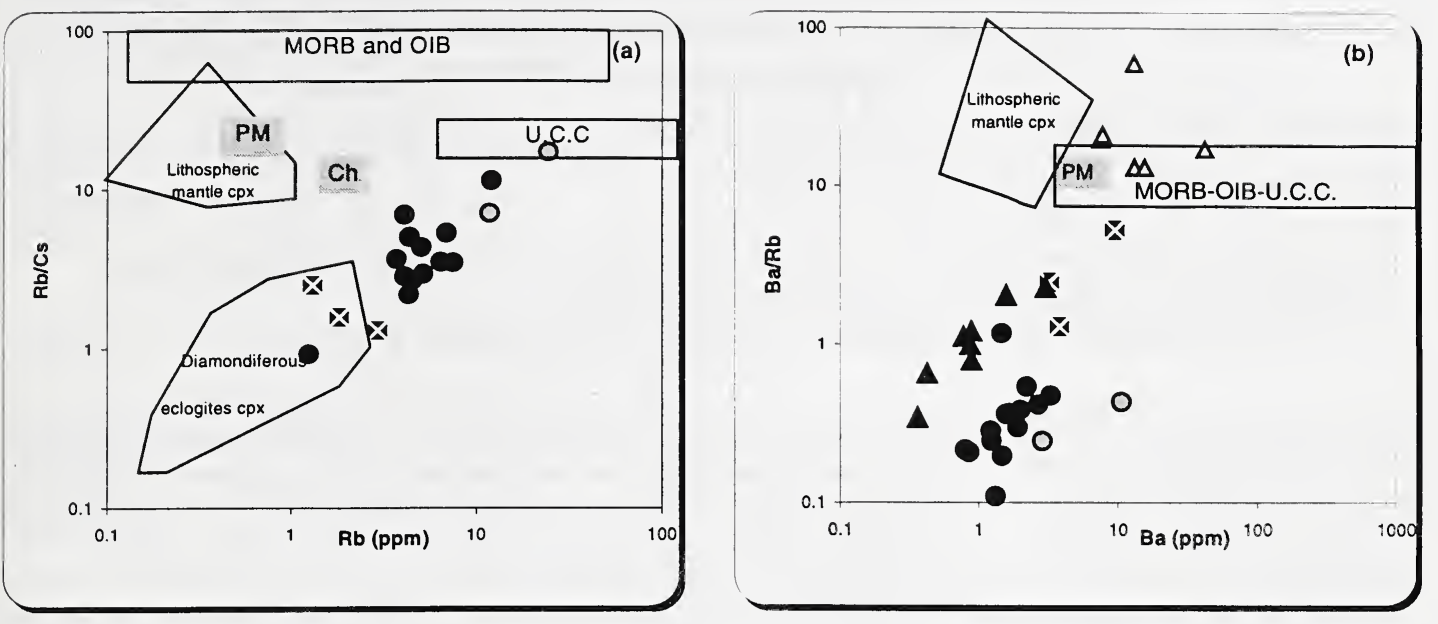

Figure 1 (a) $\mathrm{Rb} / \mathrm{Cs}$ vs. $\mathrm{Rb}$ and (b) $\mathrm{Ba} / \mathrm{Rb}$ vs. $\mathrm{Ba}$ for the overall Laserprobe ICP-MS database on $\mathrm{K}$ rich cpx: Argyle (square with white crosses), Kokchetav garnet clinopyroxenites (matrix: black circles; inclusion: grey circles) and pyroxene-dolomite rocks (black triangles) compared to fields for MORB-OIB and upper continental crust (U.C.C.) reservoirs and cpx data from lithospheric mantle (lherzolites and clinopyroxenites), and from Siberian and South African diamondiferous eclogites. The primitive mantle (PM) and chondrites values (Ch.) are shown for reference. The open triangles display the compositions of Kokchetav dolomites.
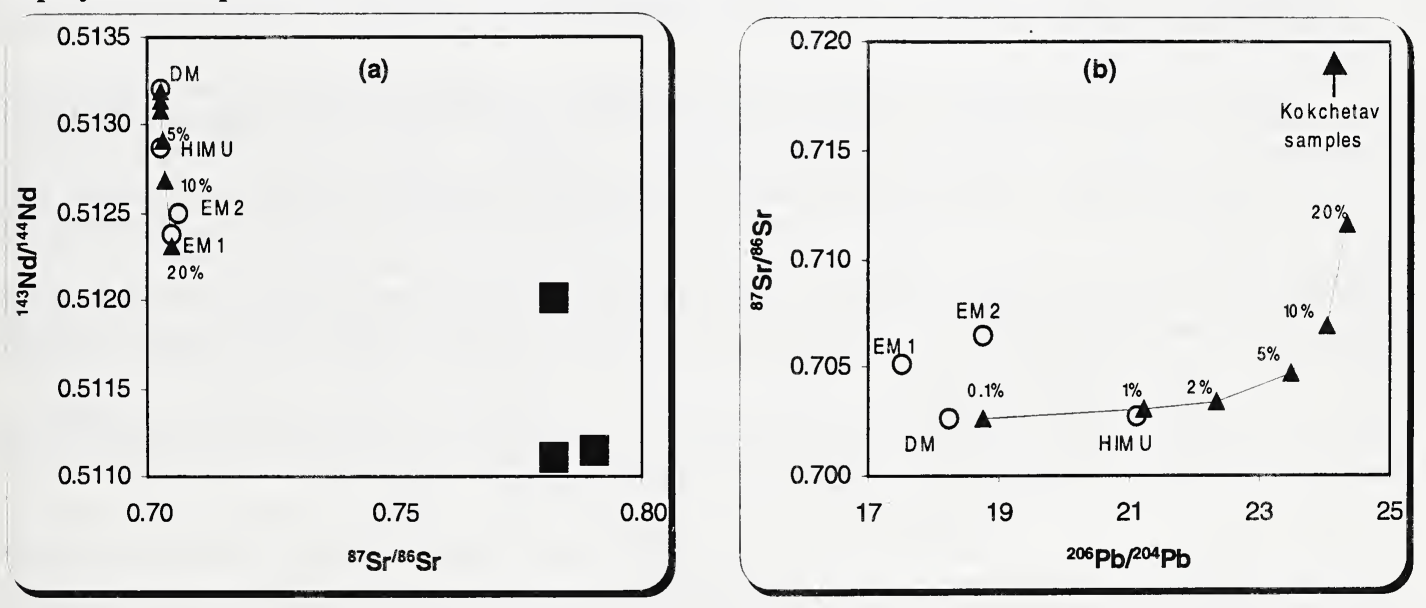

Figure 2 (a) $\mathrm{Nd}-\mathrm{Sr}$ and (b) $\mathrm{Sr}-\mathrm{Pb}$ isotopic admixture models between a depleted mantle (DM) source and Kokchetav clinopyroxenites (black squares). The small black triangles on the mixing curves indicate the wt\% of Kokchetav samples in the mixture. The open circles illustrate the location of the four main mantle isotopic end-members. 